\title{
The Influence of Eroding Djallonke Genotype on the Incidence of Diseases and Mortalities in Sahalian X Djallonke Cross-bred Sheep
}

Iddriss Ibn Abdul-Rahman ( $\square$ ai.iddriss@yahoo.co.uk)

University for Development Studies https://orcid.org/0000-0001-9619-7319

Micheal Baba Agombire

University for Development Studies

Robert Niayele

University for Development Studies

\section{Research Article}

Keywords: Djallonke, sahelian, sheep, genotype, parasites, diseases

Posted Date: September 14th, 2021

DOl: https://doi.org/10.21203/rs.3.rs-869840/v1

License: (9) (1) This work is licensed under a Creative Commons Attribution 4.0 International License. Read Full License 


\section{Abstract}

Despite cross breeding of Djallonke and Sahelian sheep due to the higher growth rate and final body weight of the Sahelian breeds over the years, little scientific evidence exists on the ability of the crosses to withstand diseases compared to their Djallonke parents. A study involving 700 Djallonke and two crosses of the Djallonke and Sahelian breeds ( $50 \%$ Sahel $\times 50 \%$ Djallonke, $75 \%$ Sahel $\times 25 \%$ Djallonke) was conducted, and documented incidence of diseases, parasites and mortalities in these animals. Enteritis (82\%), Ehrlichia ruminantium (6.2\%) and orf (6.2\%) were more prevalent in $25 \%$ Djallonke than both $100 \%$ and $50 \%$ Djallonkes. Similarly, pneumonia was more prevalent in 50\% Djallonkes, individuals of all age groups and females than all other genotypes, adults and males, respectively. Enteritis prevalence was also higher in lambs and males than animals of all age groups and females, respectively. Coccidiosis was more prevalent in individuals of all age groups and males, than lambs and females, respectively. More abscess and trauma cases were found in males than females. Significantly higher levels of tapeworms and flea infestations were seen in lambs than weaners and adults. Conversely, more mange mite and tick infestations were seen in adults than weaners and lambs. Higher levels of mortalities were recorded in all other genotypes, lambs, females and in haemoncosis cases than in $100 \%$ Djallonke, all other age groups, males and taeniasis cases, respectively. The Sahel x Djalloke crosses are more susceptible to infectious diseases and record higher mortality rates than the pure Djallonke genotypes.

\section{Introduction}

There is well documented literature on current state of knowledge for between-animal genetic variation of resistance to infections in small ruminants. These heritable differences between animals are opportunities for breeders to breed animals to enhanced tolerance to diseases (Bishop and Morris, 2007). Genetic selection has improved productivity in animals considerably over the years, with the breeding goal of creating a population with high economic production efficiency (Luiting, 1990). However, apart from a favourable increase in production, animals in a population that have been selected for high production efficiency seem to be more at risk for behavioural, physiological and immunological problems (Luiting, 1990). Broilers selected for high body weight, for instance have lower antibody response when they were challenged with sheep erythrocytes than the low body weight line (Miller et al., 1992). Nestor et al. (1996) reported higher percentage of mortality in turkeys selected for high body weight at 16 weeks compared to a random-bred control line in a natural outbreak of erysipelas. In pigs, Lacombe boars selected for high lean tissue growth rate in an experiment showed significantly more leg weakness in the foreleg (29.5\%) and rear leg (41.5\%) than non- selected control boars (Sather, 1987). Pigs with high leanness and growth rate had worse leg and osteochondrosis (OC) scores in both the elbow and the knee joint (Lundeheim, 1987). Much controversy exists about the relationship between production and health traits in Cattle. Shanks et al. (1978) compared the prevalence of diseases and digestive disorders in cows selected for high milk production and unselected controls with low genetic potential and reported $9 \%$ more cases of digestive disorders, $5 \%$ more cases of foot rot, $14 \%$ more cases of skin or skeletal disorders, $11 \%$ more cases of udder oedema and $2 \%$ more cases of mastitis.

The Djallonke sheep is the main breed in Ghana, but today large number of the Sahelian breeds are also found, especially, in the Northern part of the country (Birteeb et al., 2012). Djallonke sheep has the lowest economic traits. They take longer time to mature and give birth late, compared to the Sahelian breeds (Annor et al., 2007). The Sahelian sheep is larger in size, has higher growth rate, and is currently preferred by many farmers.

Despite the advantages of the Sahelian genotype in terms of conferring higher growth rate, higher body weight at maturity and, consequently, higher mutton yield, the genotype is said to have high mortality rate due to its susceptibility to most diseases and parasites compared to the Djallonke genotype (Goossens et al., 1999), which is said to be tolerant to most diseases and parasites. For instance, cross breeding of the Djallonke with the Sahelian sheep is said to increase the cross-breds susceptibility to trypanosomiaosis (Goossens et al., 1999). There is, however, little scientific evidence supporting this hypothesis. The present study, therefore, sought to establish the effect of eroding Djallonke genotype on the prevalence of diseases and mortalities in a flock of Sahelian $x$ Djallonke cross bred sheep. The study was specifically designed to investigate the relationship between declining Djallonke genotype (100\% Djallonke, 50\% Djallonke and 25\% Djallonke) and prevalence of diseases and parasites in Sahel x Djallonke crossbred sheep.

\section{Materials And Methods}

\section{Study location}


This study was done at the Small Ruminant Breeding Station of the Council for Scientific and Industrial Research, Nyankpala, Ghana. Nyankpala is located $16 \mathrm{~km}$ West of Tamale, and lies within latitude $90^{\circ} 25 \mathrm{~N}$ and $100^{\circ} 00^{\prime} \mathrm{N}$ and on longitude $10^{\circ} 00^{\prime} \mathrm{W}$. The area has

a unimodal rainfall pattern, and the rainy season lasts from May to October. Annual mean rainfall is $1,043 \mathrm{~mm}$. Temperatures generally fluctuate between $15^{\circ} \mathrm{C}$ and $42{ }^{\circ} \mathrm{C}$, with mean annual temperature of $28.3^{\circ} \mathrm{C}$. The mean annual day time relative humidity is $54 \%$. There is cold harmattan wind from November to February, and a period of warm dry months from March to April. The dry season is from November to April (Nyadzi, 2016).

\section{Data collection}

\section{Experimental animals and management}

Data on daily incidence of diseases and mortalities of 700 sheep were obtained from farm records, covering the period from January 2017 until December 2020. These involved animals of varying genetic composition including 100 100\% Djallonke, 375 50\% Djallonke (50\% Sahel x 50\% Djallonke), and 225 25\% Djallonke (75\% Sahel x 25\% Djallonke). About 250 males and 450 females were involved. Animals were also categorised into three groups based on age, namely: lambs (3 months of age and below; 152), weaners (over $3-12$ months of age; 250) and adults (above 12 months old; 298). All procedures used were approved by the University for Development Studies Institutional Review Board.

The animals are kept under semi-intensive system. They are allowed to graze in the field and paddocks from 9:00 am every morning until 3:00 pm. They are then given concentrates as supplementary feed. The animals are vaccinated against PPR annually. They are clinically examined every morning for ill health and treatment given where required. Prophylactic treatments were given every 1-2 months. The cause of deaths were established at the Central Veterinary Laboratory, using General Necropsy Technique (King et al., 2014), while diseases were mostly diagnosed clinically based on symptoms, and subsequently confirmed through an appropriate laboratory test at the Central Veterinary Laboratory.

Pregnant ewes are given supplementary feed in the form of concentrates to meet their nutritional requirements, and to reduce incidences of pregnancy toxaemia and other metabolic diseases during the peri-partum period, improve formation of colostrum in appropriate quantity and quality, and increase milk yield during the lactation period. During the final stage of pregnancy, health management of ewes includes administration of appropriate anthelmintic drugs, aimed at eliminating gastrointestinal helminths and preventing the build-up of parasitic burdens in the environment, and thus, reducing infection of lambs during their neonatal period. They are then moved from the breeding to the lambing pen. The ability of lambs to survive to weaning is determined by genetics, behaviour, physiology, and the environment, including on-farm management practices (Everett-Hincks and Dodds, 2008). Those lambed at the breeding pens were weighed and transferred with their mothers to the mothering pens, where they are kept and fed with supplementary feed and water. After the age of 3 weeks, the dams and lambs are allowed to graze at the paddocks. Twined, Orphaned and mis-mothered lambs that could not suck, and those from agalactic mothers were given supplementary cow milk, but most of them die of starvation due to inadequate milk supply.

\section{Data analysis}

Data was analysed using SPSS (version 20). The effects of age, sex and genotype on disease prevalence and mortalities were ascertained using the chi-square procedure. All comparisons were done at $5 \%$ significance level.

\section{Results}

\section{Effects of genotypes, age, and sex on prevalence of infectious diseases in sheep}

The effects of genotype, age and sex on prevalence of infectious diseases in Djallonke and Sahel x Djallonke crossbred sheep are shown in Table 1. The 50\% Djallonkes were more susceptible to pneumonia than both $100 \%$ and $25 \%$ Djallonkes. There was, however, no difference $(P>0.05)$ between the $100 \%$ and $25 \%$ Djallonkes in levels of susceptibility. The level of prevalence of enteritis were significantly $(P<0.05)$ higher in $25 \%$ Djallonke than all the genotypes. Similarly, 50\% Djallonkes were more $(P<0.05)$ susceptible than 
$100 \%$ Djallonkes. The 25\% Djallonkes were more susceptible to Ehrlichia ruminantum and orf than all other genotypes, while the 50\% Djallonkes were more $(P<0.05)$ susceptible to coccidiosis than all the genotypes involved. Adults were more $(P<0.05)$ susceptible to pneumonia than both weaners and lambs. Conversely, lambs were more $(P<0.05)$ prone to enteritis than both growers and adults. Lambs and adults were also more prone to Ehrlichia ruminantum than weaners. Adults and growers were more susceptible to coccidiosis than lambs. Age did not influence $(P>0.05)$ the incidence of eczema, pinkeye, mastitis, foot rot and orf. Females were more $(P<0.05)$ susceptible to pneumonia than males. Conversely, males were more $(P<0.05)$ susceptible to enteritis and coccidiosis than females. No difference $(P>0.05)$ was, however, found between males and females in the prevalence of other infectious diseases under study.

\section{Effects of genotype, age and sex on prevalence of non-infectious diseases in sheep}

There were no significant differences $(P>0.05)$ among genotypes in the prevalence of non-infectious diseases (Table 2). The prevalence of dystocia, abortion and still births in adult ewes are shown in Table 2. Weaners and adults were more $(P<0.05)$ susceptible to abscess and trauma than lambs, while lambs were more susceptible to anaemia than older animals (Table 2). Conversely, mineral deficiencies increased with increasing age $(P<0.05)($ Table 2). Significantly $(P<0.05)$ higher trauma and abscess cases were found in males than in females. On the other hand, higher $(P<0.05)$ mineral deficiencies and anaemia cases were found in females (Table 2).

Table 2

The prevalence of dystocia, abortion and still births in adult ewe

\begin{tabular}{|c|c|c|c|c|c|c|c|c|c|c|c|}
\hline & $\begin{array}{l}\text { Pneumonia } \\
\%\end{array}$ & $\begin{array}{l}\text { Enterits } \\
\%\end{array}$ & $\begin{array}{l}\text { Eczema } \\
\%\end{array}$ & $\begin{array}{l}\text { pink } \\
\text { eye } \\
\%\end{array}$ & $\begin{array}{l}\text { Ehrlichia } \\
\text { ruminantium } \\
\%\end{array}$ & $\begin{array}{l}\text { Mastitis } \\
\%\end{array}$ & $\begin{array}{l}\text { Foot } \\
\text { rot } \\
\%\end{array}$ & $\begin{array}{l}\text { Coccidiosis } \\
\%\end{array}$ & $\begin{array}{l}\text { Orf } \\
\%\end{array}$ & $X^{2}(5)$ & $\begin{array}{l}\mathrm{P} \text { - } \\
\text { value }\end{array}$ \\
\hline \multicolumn{12}{|l|}{ Genotype } \\
\hline $100 \%$ & 14.0 & 26.0 & 2.0 & 1.0 & 2.0 & 0 & 2.0 & 0 & 1.0 & 37.815 & 0.002 \\
\hline $50 \%$ & 26.0 & 34.0 & 0.2 & 0.3 & 1.4 & 0.3 & 0.3 & 3.0 & 0 & & \\
\hline $25 \%$ & 13.0 & 82.0 & 0.8 & 1.3 & 6.2 & 0 & 0 & 0 & 6.2 & & \\
\hline \multicolumn{12}{|l|}{ Age } \\
\hline Lambs & 5.0 & 91.0 & 0 & 0 & 3.9 & 0 & 0 & 0.8 & 0 & 58.957 & $\begin{array}{l}< \\
0.001\end{array}$ \\
\hline Weaners & 8.0 & 42.0 & 0.3 & 0.3 & 1.3 & 0.3 & 0 & 3.4 & 0 & & \\
\hline Adults & 39.0 & 37.1 & 1.5 & 1.5 & 4.4 & 0 & 1.1 & 5.0 & 1.5 & & \\
\hline \multicolumn{12}{|l|}{ Sex } \\
\hline Male & 6.0 & 53.3 & 0.6 & 0.6 & 2.7 & 0 & 0 & 5.0 & 0.3 & 16.977 & 0.030 \\
\hline Female & 12.2 & 44.0 & 0.8 & 0.9 & 3.3 & 0.3 & 0.8 & 2.4 & 1.1 & & \\
\hline
\end{tabular}




\begin{tabular}{|c|c|c|c|c|c|c|c|c|c|c|}
\hline & $\begin{array}{l}\text { Dystocia } \\
\%\end{array}$ & $\begin{array}{l}\text { Abscess } \\
\%\end{array}$ & $\begin{array}{l}\text { Abortion } \\
\%\end{array}$ & $\begin{array}{l}\text { Mineral } \\
\text { deficiencies } \\
\%\end{array}$ & $\begin{array}{l}\text { Still } \\
\text { births } \\
\%\end{array}$ & $\begin{array}{l}\text { Retained } \\
\text { placenta } \\
\%\end{array}$ & $\begin{array}{l}\text { Anaemia } \\
\%\end{array}$ & $\begin{array}{l}\text { Trauma } \\
\%\end{array}$ & $x^{2}(5)$ & $\begin{array}{l}P \text { - } \\
\text { value }\end{array}$ \\
\hline \multicolumn{11}{|l|}{ Genotype } \\
\hline $100 \%$ & 3.0 & 1.0 & 2.0 & 0 & 1.0 & 2.0 & 0 & 0 & 19.360 & 0.152 \\
\hline $50 \%$ & 0.3 & 0.3 & 0.8 & 1.3 & 0.3 & 0.5 & 0 & 0.5 & & \\
\hline $25 \%$ & 0.9 & 0.4 & 0 & 0 & 0.4 & 0 & 0.9 & 0.4 & & \\
\hline \multicolumn{11}{|l|}{ Age } \\
\hline Lambs & - & - & - & - & - & - & 1.6 & 0 & 36.107 & 0.001 \\
\hline Weaners & - & 0.8 & - & 0.3 & - & - & 0 & 0.3 & & \\
\hline Adults & 2.2 & 0.7 & 1.5 & 1.5 & 1 & 1.5 & 0 & 0.7 & & \\
\hline \multicolumn{11}{|l|}{ Sex } \\
\hline Male & - & 0.6 & - & 0.3 & - & - & 0 & 0.9 & 20.833 & 0.040 \\
\hline Female & 3.4 & 0.2 & 2.3 & 1.1 & 1.7 & 2.3 & 0.5 & 0 & & \\
\hline
\end{tabular}

\section{Effects of genotype, age and sex on prevalence of parasites in sheep}

Genotype and sex had no influence $(P>0.05)$ on the prevalence of ectoparasites in sheep (Table 3). However, flea infestations were higher $(P<0.05)$ in lambs than adults and weaners. Conversely, Ticks and mange mite infestations were higher $(P<0.05)$ in adults than weaners and lambs (Table 3$)$.

Genotype has no significant effect on the level of endoparasite infestation in sheep (Table 4). However, weaners, adults and females were more $(P<0.05)$ susceptible to haemonchosis than lambs and males, respectively. Conversely, lambs and males were more prone to taeniasis than older individuals and females, respectively.

\section{- The influence of genotype, age, sex, infectious and non-infectious diseases, and parasites on mortality rate in sheep}

Significantly higher $(P<0.05)$ levels of mortality occurred among the $25 \%$ and $50 \%$ Djallonkes than the $100 \%$ Djallonke genotype (Fig. 1). Mortalities in a flock of sheep due to Ehrlichia ruminantum was higher $(P<0.05)$ than mortalities due to any other disease. This was followed in descending order by enteritis, coccidiosis and pneumonia. The least cause of mortalities were Aflatoxicosis, haemorrhagic septiceamia and endometritis (Fig. 2). The predominant $(P<0.05)$ non-infectious cause of mortality in the flock was anaemia, followed by starvation and ruminal impaction. The least were trauma, dystocia and bloat (Fig. 3). Mortality rates among lambs were significantly higher $(P<0.01)$ than those in weaners and adults. Similarly, the mortality rate in weaners was higher than that in adult (Fig. 4). Significantly more females $(P<0.05)$ and animals with haemonchosis died during the study period than males (Fig. 5), and individuals with taeniasis (Fig. 6), respectively.

\section{Discussion}

The high level of susceptibility to a number of infectious diseases among the Sahelian $\times$ Djallonke crosses compared to the pure Djallonke confirms the results of Goossens et al. (1999). The authors noted that the Sahelian genotype is more susceptible to diseases and parasites compared to the Djallonke genotype. The declining Djallonke genotype in the crosses may therefore, be responsible for this heightened level of susceptibility. Courtney et al. (1985) also noted that the Florida native sheep are better able to withstand secondary infections than domestic cross-bred lambs. The differences found among the various age groups in susceptibility to infectious diseases may be due to age specificity of some diseases in sheep (Sweeney, 1996). For instance, higher level of enteritis was found in lambs than all other age groups, and this is attributable to enterotoxaemia type C, caused by Clostridium perferinges type C (MSD Veterinary Manual, 2021). Similarly, Aruni et al. (1998) reported higher level of susceptibility to infectious diseases in young than in older individuals, and attributed their observations to the under developed immunity among lambs. In contrast, Courtney et al. (1985) noted that age had little or no effects on susceptibility to infectious diseases in some breeds of sheep. 
Females were found to be less susceptible to enteritis and coccidiosis than males, and this is in line with the finding that females exhibit more-robust immune response to antigenic challenge, including infection and vaccinations than males (Fish, 2008). Courtney et al. (1985) also reported higher levels of resistance to secondary infections among ewes compared to rams, and attributed the lower immunity found in the rams to the effect of the male sex hormone on the immune cells of the body. In contrast to these findings, pneumonia was more prevalent in females than males in the present study.

The insignificant effect of genotype on the prevalence of non-infectious diseases found in the present study is dissimilar to the report of Dwyer and Bünger (2012) who noted that the Texel sheep required most assistance at birth than the Scottish blackface and the Mule ewes. This was attributed to increased lamb birth weight and litter size. The insignificant effects of genotype on the prevalence of non-infectious diseases, particularly dystocia, may therefore, be linked to the lower litter size and birth weights of the Djallonke and its crosses, compared to its temperate counterparts. The higher level of mineral deficiency in adults and females found in this study may be related to lactation, as calcium is required in milk secretion (Neville and Peaker, 1981), and poor nutrition in lactating mothers could lead to calcium deficiency (Reinhardt et al., 2011), and thus milk fever. The pastures grazed on by the animals used in the present study may be deficient in calcium and other relevant minerals.

Pralomkarn et al. (1997) reported lower haemonchus contortus burden in 100\% Thai native goats, compared to $50 \%$ Thai $\times 50 \%$ AngloNubia goats. Similarly, higher worm burden was reported in Sumatra $\times$ Java fat-tailed lambs compared to Sumatra $\times$ Barbados black belly sheep. In contrast to these findings, the results of the present study showed no differences among genotypes in the prevalence of parasites. The insignificant effects observed in the present study may be due to the fact that some of the parasites lack host specificity (Tripet and Richner, 1997). Courtney et al. (1985) reported higher level of resistance to Haemonchus contortus among ewe lambs compared to ram lambs following puberty. Similarly, Romjali et al. (1997) found higher worm burden in males than females. Windon and Dineen (1981) also reported greater immune response in female than male lambs vaccinated with irradiated larvae of Trichosostrorrgylus colllbriforrrlis. A conflicting observation was, however, made by Yakhchali and Hosseine (2006). The authors observed higher levels of infestation in female sheep and goats than males. The results of the present study partialy agree with these conflicting observations. While females were more susceptible to haemonchosis, males were more prone to taeniasis. The higher haemonchus in adults and weaners compared to lambs may be due to the fact that lambs do not go out for grazing, unlike adults and weaners that might be grazing in infested pasture

The significantly higher fleas cases observed in lambs than weaners and adults in this study is in conformity with the reports of other workers (Yeruham et al., 1997;Tesfaye et al., 2012). The authors also noted pronounced aneaemia in infested kids and lambs than adult animals. These findings are attributable to the favourable conditions such as warm weather and humidity, inappropriate litter management for fleas development (Yeruham et al., 1997) and, shorter hair and thinner skin in the young animals, allowing easy access to the skin, and enabling fleas penetration without difficulty (Tesfaye et al., 2012). It is, therefore, not surprising that more aneamia cases were found in lambs than older animals in the present study, also, mortalities in the flock were related more to aneamia than any other non-infectious cause of mortality.

The higher mortality rates observed in the crossbreds in the present study is similar to the observations of Ferreira et al. (2015) in Targhee, Dorset and East Friesian crossbreds. The authors attributed this finding to the fact that crossbreds are more susceptible to diseases and are more likely to die from those diseases than the pure native breeds. Animals genetically selected for high production efficiency have also been cited as being more prone to behavioural, physiological and immunological problems (Luiting, 1990).

Similar to the results of the present study, El-Badry (1969) reported higher mortality figures in females than males, and attributed his findings to maternal conditions and higher female population ratio. In the present study, the female population was also higher than males, since the animals were kept on the station strictly for breeding purposes. In contrast, Hazzard (1986) and Owen-Smith (1993) reported higher mortality rate in males, and suggested that females have longer lifespan than males. The higher mortality rate observed in lambs in this study may be linked to enteritis, starvation and anaemia, all of which were found to be higher in lambs than older individuals. Other authors (Yeruham et al., 1989; Mandal et al., 2007; Ferreira et al., 2015) have also related higher lamb and kid mortalities to anaemia, pneumonia, starvation, enteritis, endoparasitism and undetermined factors.

The flock mortality rate of $33 \%$ due to Ehrlichia ruminantum observed in the present study was lower than the $77.6 \%$ mortality rate reported by Mahan et al. (2001). Most (90.6\%) of the mortalities linked to endoparasitic infestations were caused by haemonchosis, and this is similar to the $87.1 \%$ reported by Fakae (1990), but higher than the $40 \%$ observed by Kagira and Kanyari (2001) in sheep. Bekele et al. (1992) reported a rate of $21.2 \%$ and $15.2 \%$ due to pneumonia and enteritis, respectively, in a flock of sheep. While the 
mortality due to pneumonia found in the present study is lower (11.7\%) than the report of Bekele et al. (1992), that due to enteritis is higher $(29.2 \%)$ than the author's report.

In conclusion, the Sahel x Djalloke crosses are more susceptible to infectious diseases, and record higher mortality rates than the pure Djallonke genotypes. The eroding Djallonke genotype, however, has no effect on the prevalence of non-infectious diseases and parasites. Ehrlichia ruminantum is the predominant infectious cause of death, while aneamia is main non-infectious cause of death in the flock. We recommend that farmers who intend to take advantage of the economic traits of the Sahalian $\times$ Djallonke cross-breds must enforce strong biosecurity measures and proper health management practices.

\section{Declarations}

\section{Acknowledgements}

The authors wish to thank the management and staff of the Animal Research Institute of the Centre for Scientific and Industrial Research, Nyankpala, for allowing us to use their facilities for the study. Funding for the project was partly provided by the Ghanaian government.

\section{Author contribution}

A.I.I. wrote the manuscript and conducted data analysis.

A.M.B. and N.R. collated data from the farm and inputted into the computer for analysis.

\section{Data availability}

The data sets analyzed during the current study are available from the corresponding author upon reasonable request.

Orcid (Abdul-Rahman II): https://orcid.org/0000-0001-9619-7319

\section{Ethical approval}

All procedures used were approved by the University for Development Studies Institutional Review Board.

Consent to participate All authors have consented to participate.

Consent to publication All authors have approved to publish.

\section{Conflicts of interest}

The authors declare that there is no conflict of interest that could be perceived as prejudicing the impartiality of the article.

\section{References}

Annor, S., Djang-Fordjour, K., \& Gyamfi, K. (2007). Is growth rate more important than survival and reproduction in sheep farming in Ghana? Journal of Science and Technology (Ghana), 27(3), 23-38.

Aruni, A., Lalitha, P., Mohan, A., Chitravelu, P., \& Anbumani, S. (1998).

Histopathological study of a natural outbreak of peste des petits ruminants in goats of Tamilnadu. Small ruminant research, 28(3), 233-240.

Bekele, T., Kasali, O., \& Woldeab, T. (1992). Causes of lamb morbidity and mortality in the Ethiopian highlands, Veterinary research communications, 16(6), 415-424. 
Birteeb, P. T., Peters, S. O., Yakubu, A., Adeleke, M. A., \& Ozoje, M. O. (2012).

Multivariate characterisation of the phenotypic traits of Djallonke and Sahel sheep in Northern Ghana. Tropical animal health and production, 45(1), 267-274.

Bishop, S., \& Morris, C. (2007). Genetics of disease resistance in sheep and goats. Small ruminant research, 70(1), 48-59.

Courtney, C. H., Parker, C., McClure, K., \& Herd, R. (1985). Resistance of exotic and domestic lambs to experimental infection with Haemonchus contortus. International journal for parasitology, 15(1), 101-109.

Dwyer, C. M., \& Bünger, L. (2012). Factors affecting dystocia and offspring vigour in different sheep genotypes, Preventive veterinary medicine, 103(4), 257-264.

El-Badry, M. (1969). Higher female than male mortality in some countries of South Asia: a digest. Journal of the American Statistical Association, 64(328), 1234-1244.

Everett-Hincks, J., \& Dodds, K. (2008). Management of maternal-offspring behavior to improve lamb survival in easy care sheep systems 12 . Journal of animal science, 86(14_suppl), E259-E270.

Fakae, B. (1990). The epidemiology of helminthosis in small ruminants under the traditional husbandry system in eastern Nigeria. Veterinary research communications, 14(5), 381-391.

Ferreira, V., Rosa, G., Berger, Y., \& Thomas, D. (2015). Survival in crossbred lambs: Breed and heterosis effects, Journal of animal science, 93(3), 912-919.

Fish, E. N. (2008). The X-files in immunity: sex-based differences predispose immune responses, Nature Reviews Immunology, 8(9), 737.

Goossens, B., Osaer, S., Ndao, M., Van Winghem, J., \& Geerts, S. (1999). The susceptibility of Djallonke and Djallonke-Sahelian crossbred sheep to Trypanosoma congolense and helminth infection under different diet levels. Veterinary parasitology, $85(1), 25-41$.

Hazzard, W. R. (1986). Biological basis of the sex differential in longevity. Journal of the American geriatrics society, 34(6), 455-471.

Kagira, J., \& Kanyari, P. (2001). The role of parasitic diseases as causes of mortality in small ruminants in a high-potential farming area in central Kenya. Journal of the South African Veterinary Association, 72(3), 150-157. 
King, J. M., Roth-Johnson, L., Dodd, D. C., \& Newsom, M. E. (2014). The Necropsy

Book: A guide for veterinary students, residents, clinicians, pathologists, and biological researchers: The Internet-First University Press.

Luiting, P. (1990). Genetic variation of energy partitioning in laying hens: causes of variation in residual feed consumption. World's Poultry Science Journal, 46(2), 133152.

Lundeheim, N. (1987). Genetic analysis of osteochondrosis and leg weakness in the Swedish pig progeny testing scheme. Acta Agriculturae Scandinavica, 37(2), 159-

173.

Mahan, S. M., Smith, G. E., Kumbula, D., Burridge, M. J., \& Barbet, A. F. (2001).

Reduction in mortality from heartwater in cattle, sheep and goats exposed to field challenge using an inactivated vaccine. Veterinary parasitology, 97(4), 295-308.

Mandal, A., Prasad, H., Kumar, A., Roy, R., \& Sharma, N. (2007). Factors associated with lamb mortalities in Muzaffarnagari sheep. Small ruminant research, 71(1-3), 273-279.

Miller, L., Siegel, P. and Dunnington, E. (1992). Inheritance of Antibody Response to Sheep Erythrocytes in Lines of Chickens Divergently Selected for Fifty-Six-Day Body Weight and Their Crosses. Poultry science, 71(1), 47-52.

MSD Veterinary Manual (2021). Enterotoxemias in Animals. Retrieved from: https://www.msdvetmanual.com/generalized-conditions/clostridialdiseases/enterotoxemias-in-animals. on 31/08/2021.

Nestor, K., Saif, Y., Zhu, J., \& Noble, D. (1996). Influence of growth selection in turkeys on resistance to Pasteurella multocida. Poultry science, 75(10), 1161-1163.

Neville, M. C., \& Peaker M. (1981). lonized calcium in milk and the integrity of the mammary epithelium in the goat. Journal of Physiology, 313, 561-570.

Nyadzi, E. (2016). Climate Variability Since 1970 and Farmers' Observations in Northern Ghana, Sustainable Agriculture Research, 5(2).

https://ageconsearch.umn.edu/record/234992

Owen-Smith, N. (1993). Comparative mortality rates of male and female kudus: the costs of sexual size dimorphism. Journal of Animal Ecology, 428-440.

Pralomkarn, W., Pandey, V., Ngampongsai, W., Choldumrongkul, S., Saithanoo, S., 
Rattaanachon, L., \& Verhulst, A. (1997). Genetic resistance of three genotypes of goats to experimental infection with Haemonchus contortus. Veterinary parasitology, $68(1-2), 79-90$.

Reinhardt, T. A., Lippolis, J. D., McCluskey, B. J., Goff, J. P., \& Horst, R. L. (2011).

Prevalence of subclinical hypocalcemia in dairy herds. The veterinary journal, $188(1), 122-124$.

Romjali, E., Pandey, V., Gatenby, R., Doloksaribu, M., Sakul, H., Wilson, A., \& Verhulst, A. (1997). Genetic resistance of different genotypes of sheep to natural infections with gastro-intestinal nematodes. Animal Science, 64(1), 97-104.

Sather, A. (1987). A note on the changes in leg weakness in pigs after being transferred from confinement housing to pasture lots. Animal Science, 44(3), 450-453.

Shanks, R., Freeman, A., Berger, P., \& Kelley, D. (1978). Effect of Selection for Milk Production and General Health of the Dairy Cow1. Journal of dairy science, 61(12), 1765-1772.

Sweeney, R. W. (1996). Transmission of paratuberculosis. Veterinary Clinics: Food Animal Practice, 12(2), 305-312.

Tesfaye, D., Assefa, M., Demissie, T., \& Taye, M. (2012). Ectoparasites of small ruminants presented at Bahir Dar Veterinary Clinic, Northwest Ethiopia. African Journal of Agricultural Research, 7(33), 4669-4674.

Tripet, F., \& Richner, H. (1997). The coevolutionary potential of a 'generalist'parasite, the hen flea Ceratophyllus gallinae. Parasitology, 115(4), 419-427.

Windon, R., \& Dineen, J. (1981). The effect of selection of both sire and dam on the response of F1 generation lambs to vaccination with irradiated Trichostrongylus colubriformis larvae. International journal for parasitology, 11(1), 11-18.

Yakhchali, M., \& Hosseine, A. (2006). Prevalence and ectoparasites fauna of sheep and goats flocks in Urmia suburb, Iran. Veterinarski arhiv, 76(5), 431-442.

Yeruham, I., Rosen, S., \& Hadani, A. (1989). Mortality in calves, lambs and kids caused by severe infestation with the cat flea Ctenocephalides felis felis (Bouché, 1835) in Israel, Veterinary parasitology, 30(4), 351-356.

Yeruham, I., Rosen, S., \& Perl, S. (1997) An apparent flea-allergy dermatitis in kids and lambs, Journal of Veterinary Medicine Series A, 44(1-10), 391-397.

Page 10/15 
Tables

Table 1: Effects of genotype, age and sex on incidences of infectious diseases

\begin{tabular}{|c|c|c|c|c|c|c|c|c|}
\hline $\begin{array}{l}\text { Pneumonia } \\
\%\end{array}$ & $\begin{array}{l}\text { Enterits } \\
\%\end{array}$ & $\begin{array}{l}\text { Eczema } \\
\%\end{array}$ & $\begin{array}{l}\text { pink } \\
\text { eye } \\
\%\end{array}$ & $\begin{array}{l}\text { Ehrlichia } \\
\text { ruminantium } \\
\%\end{array}$ & $\begin{array}{l}\text { Mastitis } \\
\%\end{array}$ & $\begin{array}{l}\text { Foot } \\
\text { rot } \\
\%\end{array}$ & $\begin{array}{l}\text { Coccidiosis } \\
\%\end{array}$ & $\begin{array}{ll}\text { Orf } & X^{2}(5) \\
\% & \end{array}$ \\
\hline
\end{tabular}

\section{Genotype}

\begin{tabular}{llllllllllll}
$100 \%$ & 14.0 & 26.0 & 2.0 & 1.0 & 2.0 & 0 & 2.0 & 0 & 1.0 & 37.815 & 0.002 \\
\hline $50 \%$ & 26.0 & 34.0 & 0.2 & 0.3 & 1.4 & 0.3 & 0.3 & 3.0 & 0 & & \\
\hline $25 \%$ & 13.0 & 82.0 & 0.8 & 1.3 & 6.2 & 0 & 0 & 0 & 6.2 &
\end{tabular}

Age

\begin{tabular}{llllllllllll} 
Lambs & 5.0 & 91.0 & 0 & 0 & 3.9 & 0 & 0 & 0.8 & 0 & 58.957 & $<.001$ \\
\hline Weaners & 8.0 & 42.0 & 0.3 & 0.3 & 1.3 & 0.3 & 0 & 3.4 & 0 & & \\
\hline Adults & 39.0 & 37.1 & 1.5 & 1.5 & 4.4 & 0 & 1.1 & 5.0 & 1.5 & \\
\hline Sex & & & & & & & & & & & \\
Male & 6.0 & 53.3 & 0.6 & 0.6 & 2.7 & 0 & 0 & 5.0 & 0.3 & 16.977 & 0.030 \\
\hline Female & 12.2 & 44.0 & 0.8 & 0.9 & 3.3 & 0.3 & 0.8 & 2.4 & 1.1 &
\end{tabular}

Table 2: The prevalence of dystocia, abortion and still births in adult ewe

\begin{tabular}{|c|c|c|c|c|c|c|c|c|c|c|}
\hline & $\begin{array}{l}\text { Dystocia } \\
\%\end{array}$ & $\begin{array}{l}\text { Abscess } \\
\%\end{array}$ & $\begin{array}{l}\text { Abortion } \\
\%\end{array}$ & $\begin{array}{l}\text { Mineral } \\
\text { deficiencies } \\
\%\end{array}$ & $\begin{array}{l}\text { Still } \\
\text { births } \\
\%\end{array}$ & $\begin{array}{l}\text { Retained } \\
\text { placenta } \\
\%\end{array}$ & $\begin{array}{l}\text { Anaemia } \\
\%\end{array}$ & $\begin{array}{l}\text { Trauma } \\
\%\end{array}$ & $X^{2}(5)$ & $\begin{array}{l}P \text { - } \\
\text { value }\end{array}$ \\
\hline \multicolumn{11}{|l|}{ Genotype } \\
\hline $100 \%$ & 3.0 & 1.0 & 2.0 & 0 & 1.0 & 2.0 & 0 & 0 & 19.360 & 0.152 \\
\hline $50 \%$ & 0.3 & 0.3 & 0.8 & 1.3 & 0.3 & 0.5 & 0 & 0.5 & & \\
\hline $25 \%$ & 0.9 & 0.4 & 0 & 0 & 0.4 & 0 & 0.9 & 0.4 & & \\
\hline \multicolumn{11}{|l|}{ Age } \\
\hline Lambs & - & - & - & - & - & - & 1.6 & 0 & 36.107 & 0.001 \\
\hline Weaners & - & 0.8 & - & 0.3 & - & - & 0 & 0.3 & & \\
\hline Adults & 2.2 & 0.7 & 1.5 & 1.5 & 1 & 1.5 & 0 & 0.7 & & \\
\hline \multicolumn{11}{|l|}{ Sex } \\
\hline Male & - & 0.6 & - & 0.3 & - & - & 0 & 0.9 & 20.833 & 0.040 \\
\hline Female & 3.4 & 0.2 & 2.3 & 1.1 & 1.7 & 2.3 & 0.5 & 0 & & \\
\hline
\end{tabular}

-Not Applicable 
Table 3: Effects of genotype, age, and sex on ectoparasite infestation

\begin{tabular}{cccccc} 
& $\begin{array}{c}\text { Mange mites } \\
\%\end{array}$ & $\begin{array}{c}\text { Fleas } \\
\%\end{array}$ & $\begin{array}{c}\text { Ticks } \\
\%\end{array}$ & $\mathbf{X}^{2}(5)$ & P-value \\
\hline Genotype & & & & \\
$100 \%$ & 5.0 & 49.0 & 25.0 & 4.610 & 0.330 \\
$50 \%$ & 1.1 & 15.0 & 10.0 & & \\
$25 \%$ & 3.1 & 43.0 & 16.0 & & \\
Age & & & & & \\
Lambs & 0.7 & 83.0 & 13.1 & 45.867 & \\
Weaners & 1.0 & 17.0 & 12.0 & & \\
Adults & 4.0 & 17.1 & 19.0 & & \\
Sex & & & & & \\
Male & 2.0 & 24.4 & 12.0 & 0.988 \\
Female & 2.4 & 34.0 & 17.1 & & \\
\hline
\end{tabular}

Table 4: Effects of genotype, age and sex on endoparasites infestation

\begin{tabular}{ccccc}
\hline Genotype & Haemonchosis & Taeniasis & $\mathrm{X}^{2}(5)$ & P - value \\
& $\%$ & $\%$ & & \\
\hline $100 \%$ & 19 & 1 & 4.341 & 0.114 \\
$50 \%$ & 10.7 & 4 & & \\
$25 \%$ & 23.1 & 7.5 & & \\
Age & & & & \\
Lambs & 3.1 & 6.3 & & \\
Weaners & 19.1 & 4.4 & & \\
Adults & 18.2 & 4.4 & & \\
Sex & & & 7.9196 & \\
Male & 11.1 & 6 & & \\
Female & 20.1 & 4 & & \\
\hline
\end{tabular}

\section{Figures}




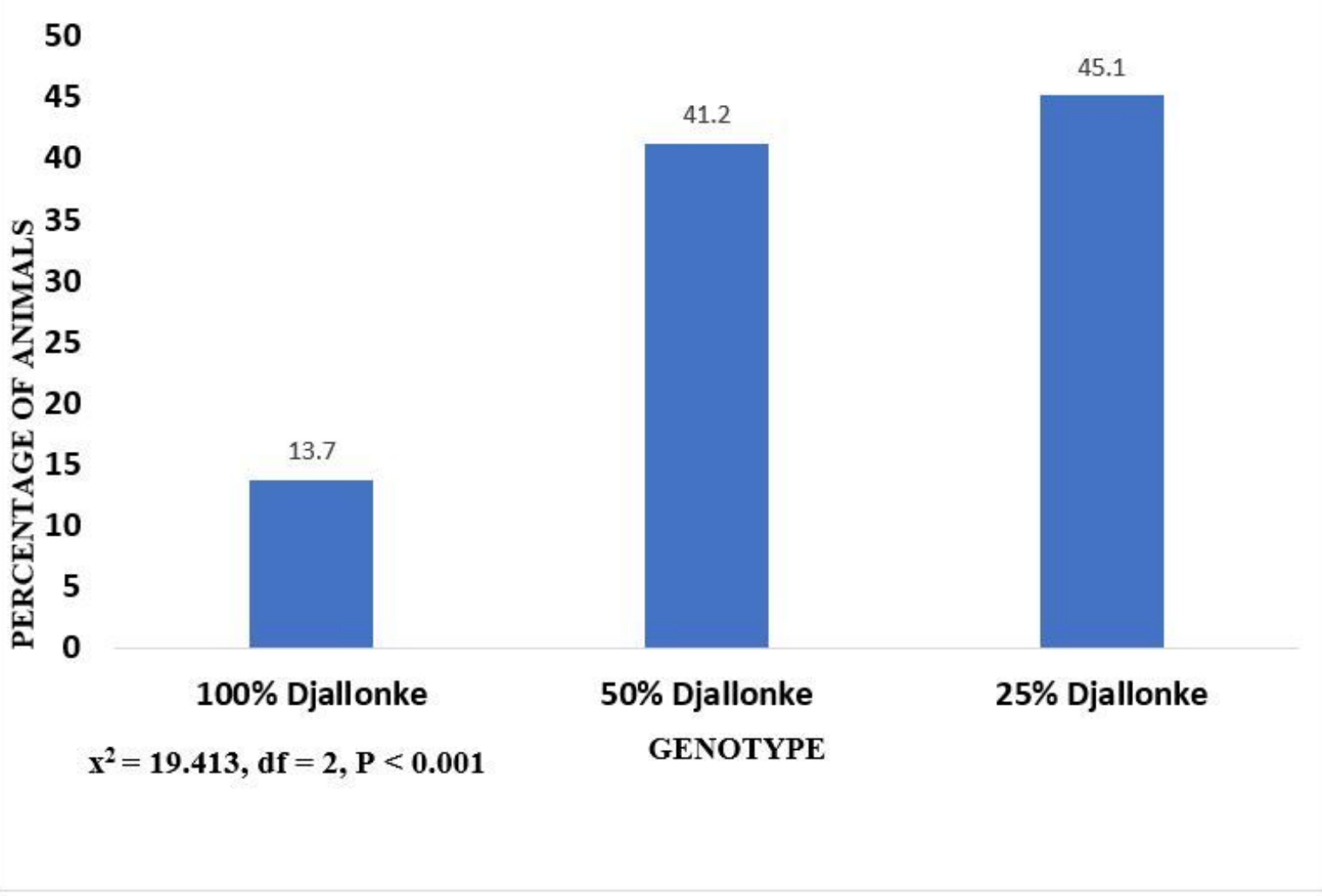

Figure 1

Relationship between genotype and mortality rate in sheep

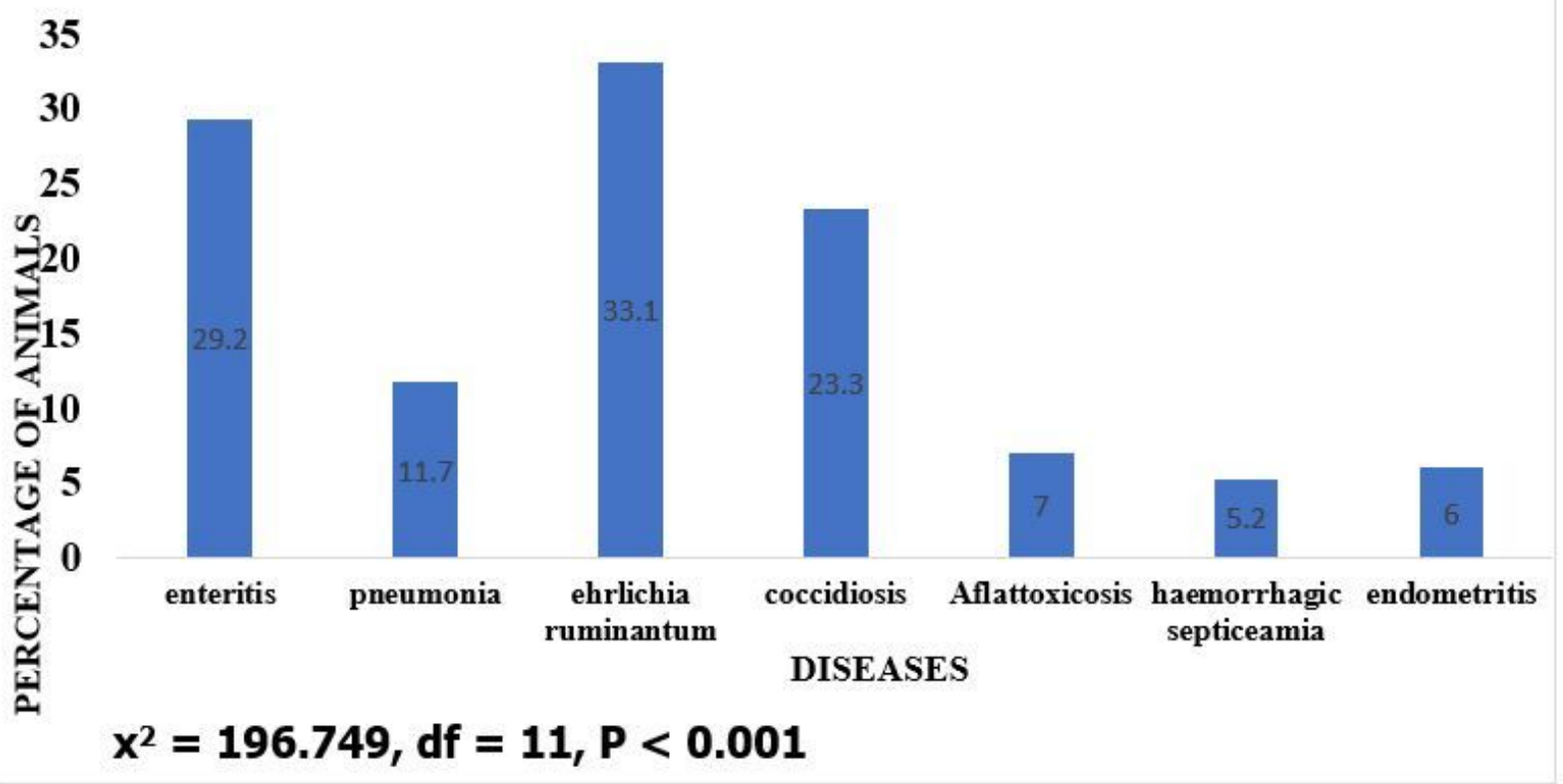

Figure 2

Relationship between mortality rate and infectious diseases in sheep 


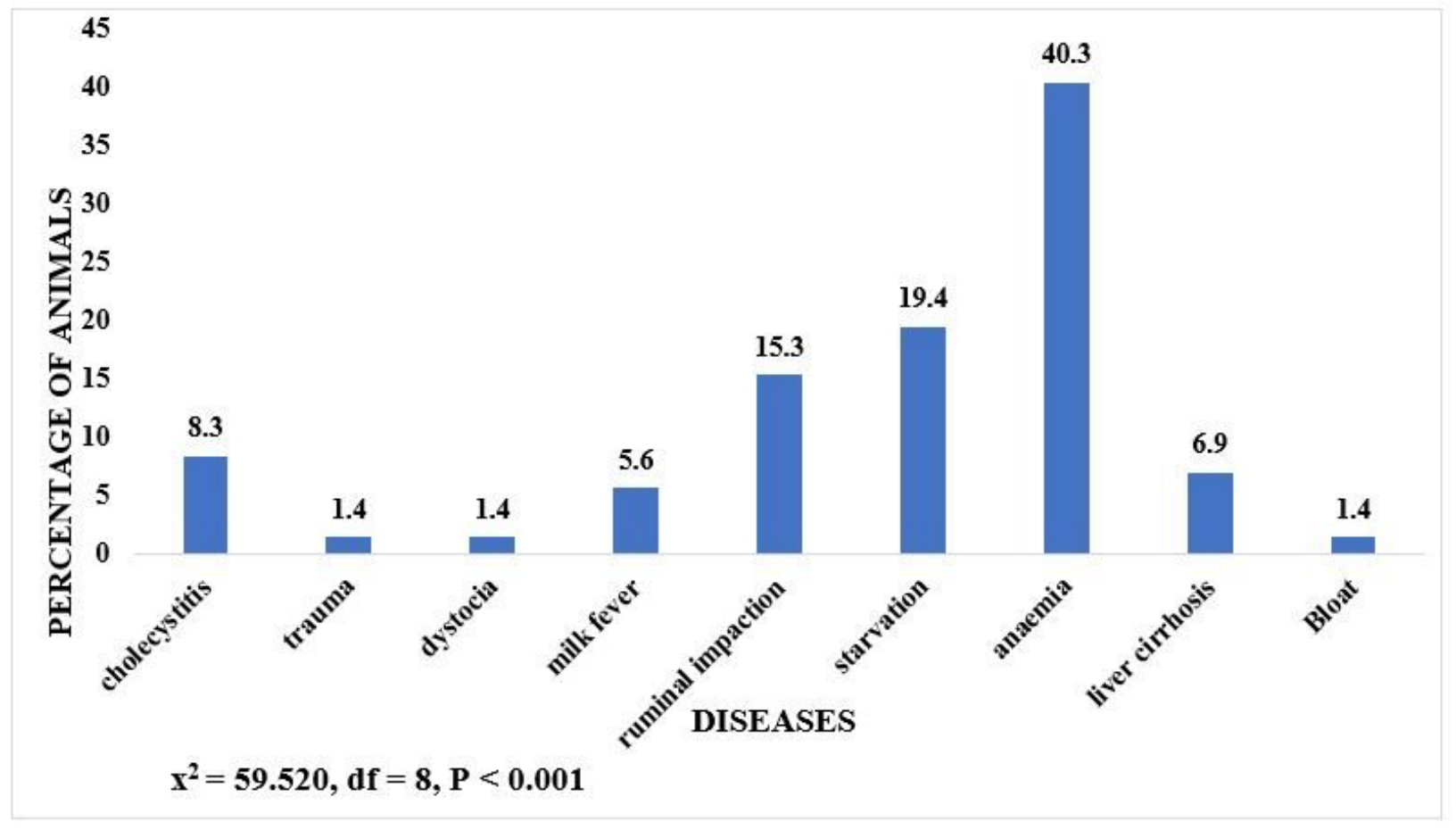

Figure 3

Relationship between non-infectious diseases and mortality rate in sheep

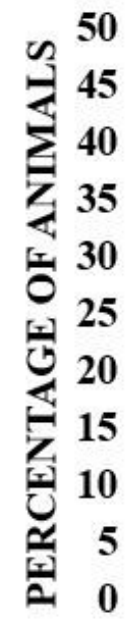

45.3

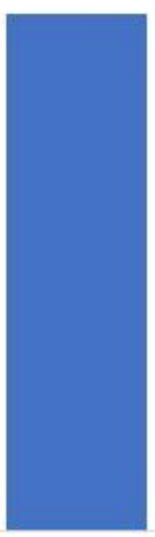

33.1

Lamb

AGE

22.6

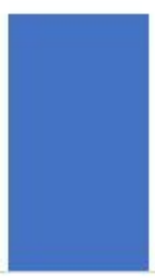

adults

$x^{2}=9.591, d f=2, P<0.008$

\section{Figure 4}

Relationship between age and mortality rate in sheep 


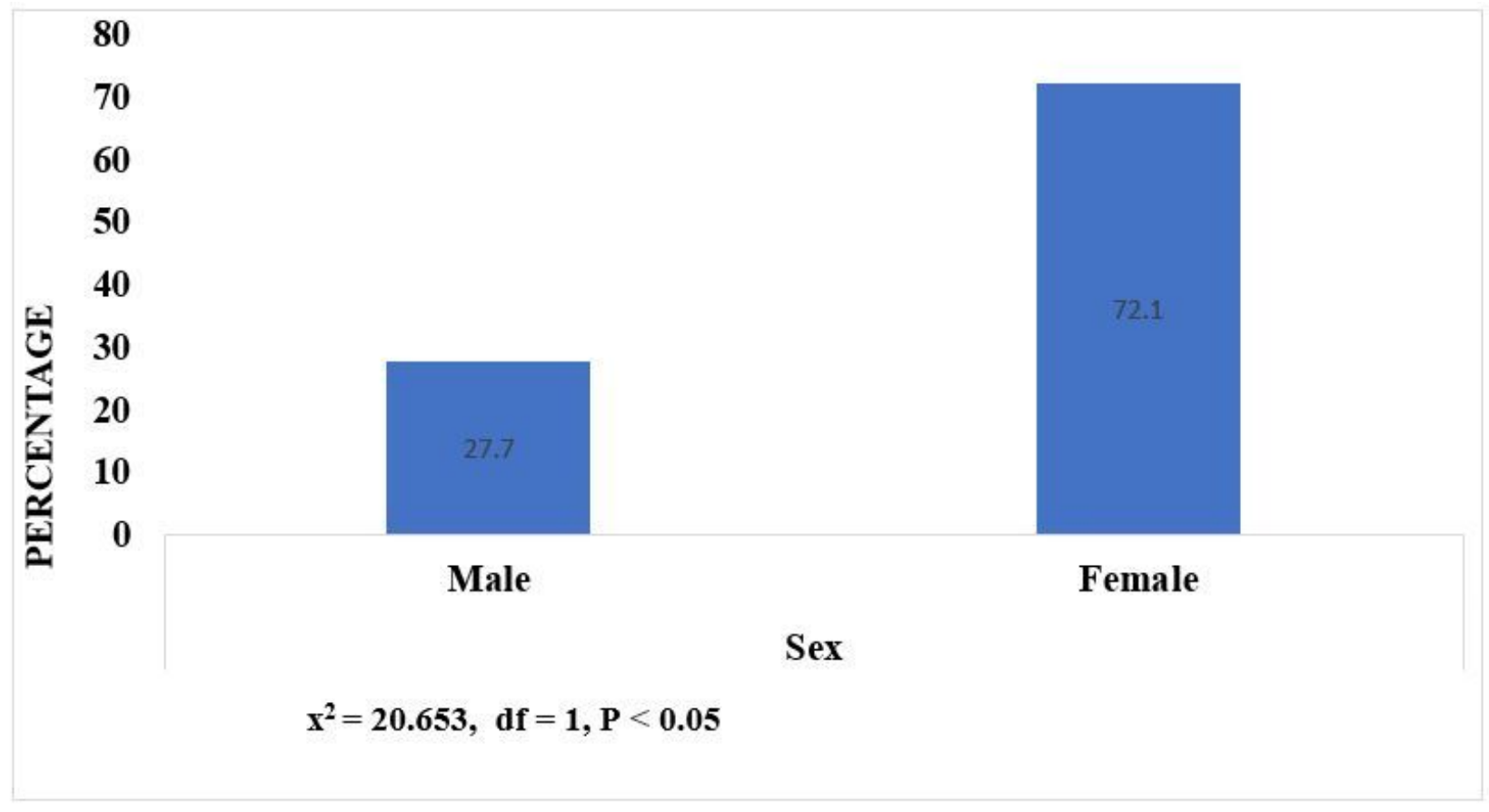

Figure 5

Relationship between sex and mortality rate in sheep

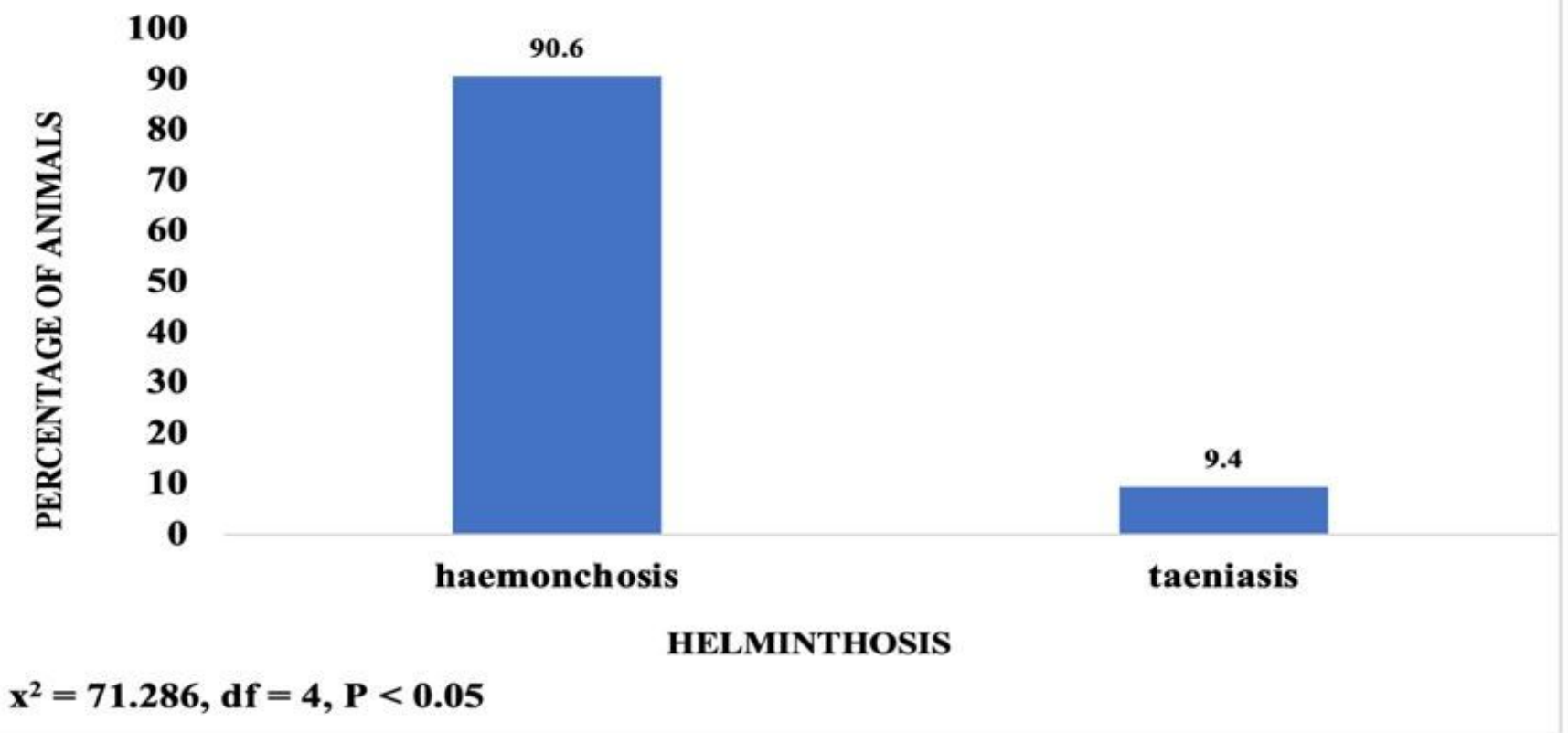

Figure 6

Relationship between endoparasite infestation and mortality rate in sleep 